\title{
Effect of heat stress on six beef breeds in the Zastron district: The significance of breed, coat colour and coat type
}

\author{
L.A. Foster ${ }^{1}$, P.J. Fourie ${ }^{1 \#}$ and F.W.C. Neser ${ }^{2}$ \\ ${ }^{1}$ Department of Agriculture, Central University of Technology Free State, Private Bag X20539, \\ Bloemfontein, South Africa \\ ${ }^{2}$ Department of Animal, Wildlife and Grassland Sciences, University of the Free State, P.O. Box 339, \\ Bloemfontein, South Africa
}

\begin{abstract}
A study was done to determine which factors had the greatest influence on a heifer's susceptibility to heat stress. Parameters tested were breed, coat colour, coat score, hide thickness, weight gain, respiration rate and body condition score. The study was conducted in the southeastern Free State. Afrikaner, Bonsmara, Braford, Charolais, Drakensberger and Simmentaler heifers were subjected to a heat tolerance trial. A total of 60 heifers, 10 of each breed were evaluated. Rectal temperature $\left(\mathrm{T}_{\mathrm{re}}\right)$ was used as a parameter to determine heat stress. The heifers were evaluated on 10 days, at 14:00 during the winter of 2007 and on seventeen days, at 14:00 during the summer of 2007/8 (after $1 \mathrm{~h}$ in the sun, no access to shade). In winter a significant difference in rectal temperature $T_{\text {re }}$ between breeds was measured on seven occasions. Phenotypical factors tested for did not affect $T_{r e}$ in winter. In summer significant differences in $T_{r e}$ were measured on 12 occasions between breeds. The following factors had a significant influence on $\mathrm{T}_{\mathrm{re}}$ in the following breeds: Afrikaner hide thickness, Bonsmara - hide thickness, Charolais - coat score.
\end{abstract}

Keywords: Heat stress, rectal temperature, breed, coat score, coat colour, and hide thickness
${ }^{\#}$ Corresponding author. E-mail: pfourie@cut.ac.za

\section{Introduction}

There is probably no other agricultural sector where there is such an extensive diversity of opinions and perspectives as in the beef industry in South Africa, being it at the level of the farmer or producer or at the level of the animal scientist. These differences are often on the subject of breed, production systems, breeding, supplementation, management, marketing and all sorts of other sentimentality (Mentz, 2002). One of the most significant reasons for these differences in opinions could be that there are hopelessly too many assumptions and philosophies without concrete evidence (Mentz, 2002). A contributing component is that breed standards on which breed improvements are mainly based are not essentially founded on biological values; they are partly synthetic devices wanting scientific basis (Bonsma, 1983).

Keeping livestock that are in harmony with the environment in which they are maintained brings about maximum utilisation of the natural recourses. There is a close correlation between an animal's physiological response (such as body temperature, respiration rate and pulse rate) and productivity. Environmental temperature is most important in determining which type of animal can be maintained in a particular region (Finch, 1986). The effects of heat on body temperature are determined not only by climate but also by the available food and water. The further an animal moves away from its preferred body temperature, the more detrimental temperature becomes to productive processes. Even small upward shifts in core temperature have profound effects on tissues and neuro-endocrine functions, which in turn reduce fertility, growth, lactation, and ability to work (Finch, 1986).

The interaction between genotype and environment ( $\mathrm{G} \times \mathrm{E})$ implies that the effect of the environment on different genotypes is not the same. This indicates that there is no universally "best" genotype - the "best" genotype will differ from one environment to another and will depend on the prevalent environmental conditions (Verscoe \& Frisch, 1990).

To the farmer $\mathrm{G} \times \mathrm{E}$ means using that particular breed of animal that is most productive in its environment. To the scientist it presents the venture of fathoming whether genetic or environmental changes are the most efficient avenues through which productivity can be enhanced. $\mathrm{G} \times \mathrm{E}$ is more consequential in 
extensive production systems since environmental variables such as nutrition, parasites, disease and climatic conditions cannot be closely controlled (Verscoe \& Frisch, 1990).

Stress, in its physical sense, cannot easily be measured in a biological system, but particular exhibitions of stress, such as changes in body temperature, heart rate and respiration can be measured because the animal responds functionally to uphold homeostasis (Du Preez, 2000).

Breed specific adaptation characters may be of the utmost importance for proper selection of cattle for specific environments. However any attention to heat tolerance of cattle should include coat colour. Colour is a feature that mediates the impact of solar radiation and affects the extent of heat load on animals. Coat colour can not be examined in isolation; similarly important is the type of coat and its interaction with colour. Structure effects penetration into, and the location of absorption of radiation within the coat (Finch et al., 1984).

The present research is an attempt to describe and evaluate breed, coat colour, coat type and body temperature (rectal temperature) in Afrikaner, Bonsmara, Braford, Charolais, Drakensberger and Simmentaler heifers in an attempt to resolve questions about these breeds adaptability to environmental temperature.

\section{Materials and Methods}

All experimental procedures were conducted on the farm "Quaggafontein", south of Zastron, in the south-eastern Free State, South Africa. Animals were farmed extensively on the natural pasture occurring in the region. Ten heifers of the Afrikaner, Bonsmara ( $5 / 8$ Afrikaner, $3 / 8$ British), Braford (5/8 Hereford, $3 / 8$ Brahman), Charolais, Drakensberger and Simmentaler breeds, all between seven and nine months of age, were introduced onto the farm during July 2007. Animals were acquired from the same area where the study was conducted to minimise the effect of adaptation. Only animals from stud breeders were selected to ensure the trueness to type of each animal.

Coat colour was divided into eight different colour groups, according to absorption rates. The groups ranged from white (score 0), grey (2), yellow-fawn (4), light-red (6), red (8), dark-red (10), brown (12), darkbrown (14) to black (16). Coat colour was assessed in August 2007 (winter) and again in December 2007 (summer).

The following is a general description of the scoring system used to describe the hair coat (Turner \& Schleger, 1960). Extremely short (score 1), very short (2), fairly short (3), fairly long (4), long (5), woolly (6), very woolly (7). Coat scoring was done once in winter and on four occasions in summer due to breed differences in the shedding process. The Bonsmara and Simmentaler heifers had to be withdrawn from the research in February 2008 due to conflicting breeding programmes.

Body condition was appraised according to the scores of thin (1 - 3), borderline (4), optimum (5 - 6), and fat (7) and was determined on three occasions from January to March of 2008.

Skin-fold thickness was determined using a calliper. The skin over the mid-side area was measured as Tulloh (1961) found that the skin over this area is relatively uniform in thickness. Skin-fold thickness was measured in December 2007 and again in January 2008. An additional skin-fold measurement was taken in March 2008 on the Afrikaner, Braford, Charolais and Drakensberger heifers.

Body temperature (rectal temperature) of the same ten heifers of each breed which did experience heat stress during December 2007 and January 2008 (THI > 70, 10-day period) was measured. An additional seven measurements were taken during February 2008 on the Afrikaner, Braford, Charolais and Drakensberger heifers. On days when data was recorded, animals were rounded up and placed in a pen at 13:00. The measuring of rectal temperatures commenced at 14:00.

Respiratory rate $\left(\mathrm{R}_{\mathrm{r}}\right)$ was counted visually from flank movements in a given time as recorded with a chronometer. Respiratory rate was measured on five individual events in December 2007 and again on six separate occasions in February 2008 on the Afrikaner, Braford, Charolais and Drakensberger. The $R_{r}$ was determined concurrently with the rectal temperatures.

A Kestrel ${ }^{\mathbb{B}} 4000$ Pocket Weather Tracker was used to measure weather information at 14:00. The best, simplest and most practical parameter for the measurement of environmental temperature, which may cause heat stress in cattle, is the Temperature Humidity Index (THI). The Livestock Weather Safety Index (LWSI) of the Livestock Conservation Institute (1970) was used as a basis for classifying various categories of the THI values. The classification of values is as follows: Normal (70 or less), alert (71 - 78), danger (79 - 83), 
emergency (83 and above) (Du Preez, 2000). Data was statistically analysed using analysis of variance in Proc GLM to determine the effect of the different parameters.

\section{Results and Discussion}

It was found that coat colour was a function of breed and due to this, the parameter breed rather than coat colour, was used when data were analyzed.

The results of the study show that highly significant differences in coat scores between breeds were found. Coat scores were affected by season as mean breed coat scores decreased from August through to February. The Afrikaner had the lowest coat score on the $1^{\text {st }}, 3^{\text {rd }}, 4^{\text {th }}$ and $5^{\text {th }}$ sampling days and the Charolais the highest coat score throughout the course of the study. Bonsma repeatedly stresses the importance of coat type in adaptation (Bonsma, 1983). Turner \& Schleger (1960) indicate the potential value of coat characters in selecting tropical beef cattle. However, they conclude that a sleek coat may have a greater significance as an indicator of metabolic efficiency or of a capacity to react favourably to stress.

Table 1 Least-squares breed means ( \pm s.e.) for coat score (CS), 1 being extremely short and 7 very woolly

\begin{tabular}{llllllll}
\hline $\begin{array}{l}\text { Para- } \\
\text { meter }\end{array}$ & Month & $\begin{array}{l}\text { Afrikaner } \\
(\mathrm{n}=10)\end{array}$ & $\begin{array}{l}\text { Bonsmara } \\
(\mathrm{n}=10)\end{array}$ & $\begin{array}{l}\text { Braford } \\
(\mathrm{n}=10)\end{array}$ & $\begin{array}{l}\text { Charolais } \\
(\mathrm{n}=10)\end{array}$ & $\begin{array}{l}\text { Drakensberger } \\
(\mathrm{n}=10)\end{array}$ & $\begin{array}{l}\text { Simmentaler } \\
(\mathrm{n}=10)\end{array}$ \\
\hline CS 1 & August & $3.6^{\mathrm{a}} \pm 0.16$ & $4.3^{\mathrm{b}} \pm 0.15$ & $4.8^{\mathrm{b}} \pm 0.13$ & $6.4^{\mathrm{c}} \pm 0.16$ & $4.7^{\mathrm{b}} \pm 0.15$ & $6.2^{\mathrm{c}} \pm 0.13$ \\
CS 2 & December & $3.2^{\mathrm{ab}} \pm 0.20$ & $2.8^{\mathrm{a}} \pm 0.20$ & $3.0^{\mathrm{a}} \pm 0.26$ & $4.0^{\mathrm{b}} \pm 0.21$ & $3.5^{\mathrm{ab}} \pm 0.27$ & $3.5^{\mathrm{ab}} \pm 0.22$ \\
CS 3 & January & $1.7^{\mathrm{a}} \pm 0.15$ & $1.9^{\mathrm{a}} \pm 0.18$ & $2.7^{\mathrm{bc}} \pm 0.21$ & $3.6^{\mathrm{d}} \pm 0.16$ & $2.2^{\mathrm{ab}} \pm 0.13$ & $3.1^{\mathrm{cd}} \pm 0.10$ \\
CS 4 & February & $1.3^{\mathrm{a}} \pm 0.15$ & - & $2.5^{\mathrm{b}} \pm 0.17$ & $3.4^{\mathrm{c}} \pm 0.16$ & $1.7^{\mathrm{a}} \pm 0.15$ & - \\
CS 5 & March & $1.1^{\mathrm{a}} \pm 0.10$ & - & $2.5^{\mathrm{b}} \pm 0.17$ & $4.0^{\mathrm{c}} \pm 0.26$ & $1.8^{\mathrm{d}} \pm 0.13$ & -
\end{tabular}

${ }^{1}$ Means in the same row with different superscripts differ significantly at $\mathrm{P}<0.0001$, with the exception of the second day of sampling (CS2) where the significant difference in CS between breeds was $\mathrm{P}<0.01$.

Highly significant $(\mathrm{P}<0.0001)$ breed differences in body condition score were reported throughout the course of the study. The Braford heifers had the highest mean BCS and the Charolais heifers' the lowest mean BCS throughout the duration of the research. On the basis of mean BCS, the breeds have been ranked in order of decreasing BCS as Braford $>$ Afrikaner, Bonsmara, Drakensberger $>$ Simmentaler $>$ Charolais.

Table 2 Least-squares breed means ( \pm s.e.) for body condition score (BCS), 1 being thin and 9 obese

\begin{tabular}{lllllll}
\hline Parameter & $\begin{array}{l}\text { Afrikaner } \\
(\mathrm{n}=10)\end{array}$ & $\begin{array}{l}\text { Bonsmara } \\
(\mathrm{n}=10)\end{array}$ & $\begin{array}{l}\text { Braford } \\
(\mathrm{n}=10)\end{array}$ & $\begin{array}{l}\text { Charolais } \\
(\mathrm{n}=10)\end{array}$ & $\begin{array}{l}\text { Drakensberger } \\
(\mathrm{n}=10)\end{array}$ & $\begin{array}{l}\text { Simmentaler } \\
(\mathrm{n}=10)\end{array}$ \\
\hline BCS 1 & $6.4^{\mathrm{ab}} \pm 0.16$ & $6.4^{\mathrm{ab}} \pm 0.16$ & $6.9^{\mathrm{a}} \pm 0.10$ & $5.4^{\mathrm{c}} \pm 0.16$ & $6.2^{\mathrm{b}} \pm 0.13$ & $5.9^{\mathrm{bc}} \pm 0.10$ \\
BCS 2 & $7.0^{\mathrm{a}} \pm 0.00$ & - & $7.0^{\mathrm{a}} \pm 0.00$ & $5.6^{\mathrm{b}} \pm 0.16$ & $6.8^{\mathrm{a}} \pm 0.13$ & - \\
BCS 3 & $7.0^{\mathrm{a}} \pm 0.00$ & - & $7.9^{\mathrm{b}} \pm 0.31$ & $5.3^{\mathrm{c}} \pm 0.15$ & $6.9^{\mathrm{a}} \pm 0.10$ & -
\end{tabular}

${ }^{1}$ Means in the same row with different superscripts differ significantly at $\mathrm{P}<0.0001$.

With regards to hide-thickness, highly significant $(\mathrm{P}<0.0001)$ differences were reported between breeds. The Afrikaner heifers had the thickest hide throughout the course of the research and the Charolais heifers the thinnest hide. No significant differences in hide thicknesses were noted between the Bonsmara, Braford, Drakensberger and Simmentaler heifers.

Respiration rate was measured on eleven events. The $\mathrm{R}_{\mathrm{r}}$ rate between breeds differed significantly $(\mathrm{P}<$ 0.01 ) only on two occasions. On both occasions where a significant difference in $R_{r}$ was detected the Drakensberger heifers had the lowest respiration rate at an average of 41.6 and 35.6 breaths per minute and the Braford heifers the highest at 54.8, and 63.6 breaths per minute. 
Table 3 Least-squares breed means ( \pm s.e.) for hide-thickness $(\mathrm{H})$ measured in millimetres

\begin{tabular}{lllllll}
\hline $\begin{array}{l}\text { Para- } \\
\text { Meter }\end{array}$ & $\begin{array}{l}\text { Afrikaner } \\
(\mathrm{n}=10)\end{array}$ & $\begin{array}{l}\text { Bonsmara } \\
(\mathrm{n}=10)\end{array}$ & $\begin{array}{l}\text { Braford } \\
(\mathrm{n}=10)\end{array}$ & $\begin{array}{l}\text { Charolais } \\
(\mathrm{n}=10)\end{array}$ & $\begin{array}{l}\text { Drakensberger } \\
(\mathrm{n}=10)\end{array}$ & $\begin{array}{l}\text { Simmentaler } \\
(\mathrm{n}=10)\end{array}$ \\
\hline H 1 & $14.1^{\mathrm{a}} \pm 0.52$ & $12.6^{\mathrm{ab}} \pm 0.60$ & $12.8^{\mathrm{ab}} \pm 0.51$ & $8.0^{\mathrm{c}} \pm 0.30$ & $11.5^{\mathrm{b}} \pm 0.43$ & $11.4^{\mathrm{b}} \pm 1.38$ \\
H 2 & $14.6^{\mathrm{a}} \pm 0.47$ & $12.4^{\mathrm{b}} \pm 0.52$ & $12.6^{\mathrm{b}} \pm 0.43$ & $7.9^{\mathrm{c}} \pm 0.43$ & $11.0^{\mathrm{b}} \pm 0.49$ & $12.1^{\mathrm{b}} \pm 0.77$ \\
H 3 & $16.4^{\mathrm{a}} \pm 0.16$ & - & $14.5^{\mathrm{b}} \pm 0.54$ & $10.4^{\mathrm{c}} \pm 0.40$ & $13.4^{\mathrm{b}} \pm 0.31$ & -
\end{tabular}

${ }^{1}$ Means in the same row with different superscripts differ significantly at $\mathrm{P}<0.0001$

Highly significant differences $(\mathrm{P}<0.01)$ in rectal temperatures between breeds were measured as illustrated in Table 4. No significant difference in $\mathrm{T}_{\mathrm{re}}$ was measured between the Afrikaner, Bonsmara, Braford and Drakensberger heifers as well as between the Charolais and Simmentaler heifers. However the Charolais and Simmentaler heifers' rectal temperatures differed significantly $(\mathrm{P}<0.01)$ from that of the rectal temperatures of the Afrikaner, Bonsmara, Braford and Drakensberger heifers.

Table 4 Least squares breed means ${ }^{1}$ and (s.e) of rectal temperatures $\left(\mathrm{T}_{\mathrm{re}}\right)$ in summer

\begin{tabular}{|c|c|c|c|c|c|c|c|}
\hline $\begin{array}{l}\text { Para- } \\
\text { meter }\end{array}$ & THI & $\begin{array}{l}\text { Afrikaner } \\
(\mathrm{n}=10)\end{array}$ & $\begin{array}{l}\text { Bonsmara } \\
(\mathrm{n}=10)\end{array}$ & $\begin{array}{l}\text { Braford } \\
(\mathrm{n}=10)\end{array}$ & $\begin{array}{l}\text { Charolais } \\
(\mathrm{n}=10)\end{array}$ & $\begin{array}{l}\text { Drakensberger } \\
(\mathrm{n}=10)\end{array}$ & $\begin{array}{l}\text { Simmentaler } \\
(\mathrm{n}=10)\end{array}$ \\
\hline $\mathrm{T}_{\mathrm{re}} 1$ & 73 & $39.45 \pm 0.18$ & $39.39 \pm 0.07$ & $39.50 \pm 0.17$ & $39.60 \pm 0.06$ & $39.43 \pm 0.09$ & $39.40 \pm 0.07$ \\
\hline $\mathrm{T}_{\mathrm{re}} 2$ & 78 & $39.43 \pm 0.20$ & $39.34 \pm 0.05$ & $39.53 \pm 0.21$ & $39.44 \pm 0.06$ & $39.37 \pm 0.09$ & $39.59 \pm 0.15$ \\
\hline $\mathrm{T}_{\mathrm{re}} 3$ & 80 & $39.26 \pm 0.09$ & $39.23 \pm 0.04$ & $39.40 \pm 0.15$ & $39.56 \pm 0.12$ & $39.38 \pm 0.17$ & $39.59 \pm 0.14$ \\
\hline $\mathrm{T}_{\mathrm{re}} 4$ & 77 & $39.18^{\mathrm{a}} \pm 0.08$ & $39.20^{\mathrm{a}} \pm 0.06$ & $39.38^{\mathrm{ab}} \pm 0.13$ & $39.74^{b} \pm 0.18$ & $39.26^{\mathrm{a}} \pm 0.04$ & $39.54^{\mathrm{ab}} \pm 0.08$ \\
\hline $\mathrm{T}_{\mathrm{re}} 5$ & 78 & $39.22^{a} \pm 0.09$ & $39.52^{\mathrm{ab}} \pm 0.14$ & $39.57^{\mathrm{ab}} \pm 0.19$ & $39.81^{b} \pm 0.04$ & $39.56^{\mathrm{ab}} \pm 0.06$ & $39.72^{b} \pm 0.09$ \\
\hline $\mathrm{T}_{\mathrm{re}} 6$ & 69 & $38.88^{a} \pm 0.14$ & $39.01^{\mathrm{ab}} \pm 0.05$ & $38.95^{\mathrm{ab}} \pm 0.05$ & $39.30^{b} \pm 0.10$ & $38.95^{\mathrm{ab}} \pm 0.07$ & $39.26^{b} \pm 0.06$ \\
\hline $\mathrm{T}_{\mathrm{re}} 7$ & 69 & $38.79^{a} \pm 0.58$ & $38.93^{\mathrm{ab}} \pm 0.05$ & $38.85^{\mathrm{a}} \pm 0.05$ & $39.25^{c} \pm 0.04$ & $38.85^{\mathrm{a}} \pm 0.06$ & $39.11^{b c} \pm 0.07$ \\
\hline $\mathrm{T}_{\mathrm{re}} 8$ & 70 & $38.91^{\mathrm{a}} \pm 0.04$ & $39.00^{\mathrm{abc}} \pm 0.05$ & $38.99^{\mathrm{ab}} \pm 0.10$ & $39.21^{\mathrm{bc}} \pm 0.03$ & $38.90^{\mathrm{a}} \pm 0.07$ & $39.26^{\mathrm{c}} \pm 0.07$ \\
\hline $\mathrm{T}_{\mathrm{re}} 9$ & 76 & $39.06^{\mathrm{a}} \pm 0.05$ & $39.07^{\mathrm{a}} \pm 0.05$ & $38.96^{\mathrm{a}} \pm 0.06$ & $39.37^{b} \pm 0.05$ & $39.13^{\mathrm{ab}} \pm 0.06$ & $39.36^{\mathrm{b}} \pm 0.08$ \\
\hline $\mathrm{T}_{\mathrm{re}} 10$ & 78 & $39.31^{\mathrm{ab}} \pm 0.08$ & $39.51^{\mathrm{ab}} \pm 0.15$ & $39.17^{\mathrm{a}} \pm 0.06$ & $39.74^{b} \pm 0.13$ & $39.34^{\mathrm{ab}} \pm 0.11$ & $39.56^{\mathrm{ab}} \pm 0.07$ \\
\hline $\mathrm{T}_{\mathrm{re}} 11$ & 81 & $39.18^{\mathrm{a}} \pm 0.09$ & - & $39.16^{\mathrm{a}} \pm 0.07$ & $39.47^{b} \pm 0.04$ & $39.20^{\mathrm{a}} \pm 0.03$ & . \\
\hline $\mathrm{T}_{\mathrm{re}} 12$ & 80 & $39.03^{a} \pm 0.05$ & - & $38.97^{\mathrm{a}} \pm 0.05$ & $39.41^{\mathrm{b}} \pm 0.05$ & $39.04^{\mathrm{a}} \pm 0.05$ & - \\
\hline $\mathrm{T}_{\mathrm{re}} 13$ & 80 & $39.08^{\mathrm{a}} \pm 0.04$ & - & $39.09^{\mathrm{a}} \pm 0.07$ & $39.56^{b} \pm 0.06$ & $39.09^{\mathrm{a}} \pm 0.04$ & . \\
\hline $\mathrm{T}_{\mathrm{re}} 14$ & 81 & $39.11^{\mathrm{a}} \pm 0.06$ & _ & $39.05^{\mathrm{a}} \pm 0.07$ & $39.72^{b} \pm 0.08$ & $38.98^{\mathrm{a}} \pm 0.05$ & _ \\
\hline $\mathrm{T}_{\mathrm{re}} 15$ & 73 & $39.11^{\mathrm{a}} \pm 0.05$ & - & $38.95^{\mathrm{a}} \pm 0.06$ & $39.55^{b} \pm 0.06$ & $39.04^{\mathrm{a}} \pm 0.07$ & - \\
\hline $\mathrm{T}_{\mathrm{re}} 16$ & 80 & $38.96 \pm 0.13$ & - & $39.35 \pm 0.23$ & $39.60 \pm 0.25$ & $39.03 \pm 0.10$ & - \\
\hline $\mathrm{T}_{\mathrm{re}} 17$ & 79 & $39.00^{\mathrm{ab}} \pm 0.10$ & - & $38.83^{a} \pm 0.06$ & $39.21^{b} \pm 0.05$ & $38.97^{\mathrm{ab}} \pm 0.15$ & . \\
\hline
\end{tabular}

${ }^{1}$ Means in the same row with different superscripts differ significantly at $\mathrm{P}<0.01$.

\section{Conclusions}

From the results of this study it is clear that breed is the only parameter measured that influenced rectal temperature and thus heat tolerance in all the animals. The following factors had a significant influence $(\mathrm{P}<0.05)$ on the rectal temperatures in the following breeds: Afrikaner - hide thickness, Bonsmara - hide thickness, Charolais - coat score. It would appear that the Charolais and Simmentaler heifers would be more prone to suffer from heat stress as these breeds had elevated rectal temperatures on hot days compared to the other breeds.

\section{Acknowledgements}

The author would like to thank the NRF for financial support. 


\section{References}

Bonsma, J.C., 1983. Man Must Measure. Applied Genetics Publishing Inc. Cody, Wyoming, USA.

Dowling, D.F., 1956. An experimental study of heat tolerance of cattle. Aust. J. Agric. Res. 7, 469-483.

Du Preez, J.H., 2000. Parameters for the determination and evaluation of heat stress in dairy cattle in South Africa. Onderstepoort J. Vet. Res. 67, 263-271.

Finch, V.A., 1986. Body temperature in beef cattle: It's control and relevance to production in the tropics. J. Anim. Sci. 62, 531-542.

Finch, V.A., Bennet, I.L. \& Holmes, C.R., 1984. Coat colour: effect on thermal balance, behaviour and growth, and relationship with coat type. J. Agric. Sci., Camb. 102, 141-147.

Livestock Conservation Institute, 1970. Information release. Patterns of transit losses. Omaha, Neb: Livestock Conservation. Inc.

Mentz, A., 2002. Perspektiewe oor Beesboerdery in Suider-Afrika. Waarhede of Leuens?, Highveld Herald. Ermelo, pp.1-7.

Tulloh, N.M., 1961. Variations in the skin and skin-fold thickness of beef cattle [Online]. CSIRO Publishing: http://www.publish.csiro.au/paper

Turner, H.G. \& Schleger, A.V., 1960. The significance of coat type in cattle. Aust. J. Agric. Res. 11, 645-663.

Verscoe, J.E. \& Frisch, J.E., 1990. Genotype and environment interaction with particular reference to cattle in the tropics. Fifth AAAP, Taipei, HL-19, 2, 185-210. 